\title{
Improving Students` Vocabulary Mastery Through Observe and Remember Game at the Seventh Grade SMPN 2 Palopo
}

\author{
Helma \\ State Islamic Institute of Palopo (IAIN Palopo), Indonesia \\ helma@iainpalopo.ac.id
}

\begin{abstract}
This thesis is about Improving Students Mastery Vocabulary Through Observe and Remember the game at the Seventh Grade SMPN 2 Palopo. The problem statement of this thesis: Is the use of Observe and Remember the game useful to improve the students' vocabulary at the seventh grade SMPN 2 Palopo? The objective of the research: To find out whether or not the use of Observe and Remember the game is effective in improving students' vocabulary in the seventh grade SMPN 2 Palopo. This research applied pre-experimental. The population of this research was the seventhgrade students of SMPN 2 Palopo. The population there is only one class that consists of 30 students, and the taking sample technique is total sampling. The instrument of the research was a vocabulary test. The pre-test was given to know the basic ability of the students' vocabulary and the post-test given to know the students' improvement in students' vocabulary after given the treatment and the research used to observe and remember the game. Then the test was calculated and analyzed using SPSS 20 . The researcher can conclude that using Observe and Remember games is useful in improving students' vocabulary at the seventh grade SMPN 2 Palopo. It was proven by a significant difference between the students' mean score of pre-test and post-test. In the pre-test, the students' mean score is 51.00, and the students' score in the post-test is 92.33 . Observe and remember the game can improve students'vocabulary because students are active in learning English. Besides, using the game can improve communication between students and teachers when learning processes.
\end{abstract}

Keywords: Observe and Remember Game, Teaching Vocabulary, Vocabulary Mastery

\section{INTRODUCTION}

In English, there are some skills and the basics of a foreign language are mainly in improving the development of English in the form of vocabulary. Where by having vocabulary can help to make English conversation. So the talk we can run smoothly with the mastery of vocabulary in stages. Vocabulary is a set of word that instrumental at English in forming a sentence, which expresses his thoughts and feelings about the content perfectly, whether oral or written. Vocabulary is one way to improve English skill and talking about English definitely require vocabulary. Student will not be proficient in English if they do not master a lot of vocabulary. English without vocabulary students cannot read, write, speak and listen to English conversation. According to Martin Manser, generally the language skills are listening, speaking; reading as well as writing and its components consist of grammar, vocabulary, and pronunciation (Iksan, n.d.).

Vocabulary is a language center and of critical necessary for the typical language learners. Lack of vocabulary give result lack of meaning full communication. Vocabulary is one of the language elements the need for be acquir by English learner. Vocabulary does 
very necessary to study language because the people can' not communicated without enough vocabulary. Vocabulary is one more important because it can understand everything that wants to be communicated and knows the fundamental principles, whether in general or individual situations.

Based on pre-survey the writer found that the learners were lack of interest in learning English especial in vocabulary. Because the teacher only explains the material and then assigns the task.How to teach it without using games or media. So, students are lazy to learn thing like that will not be able to improve learning English. While some scholars introduced that games are very helpful in English language teaching, one mentioned that the game is very motivating because this game does fun and interesting. We commit be use to provide training in all language skill and are use to practice various type from communication.(Ersöz, 2000). Also mentioned that there are four type of game, they are class game, individual game, couple work game, and group work game. (Wright Andrew, Betteridge David, 2006)

Related to this issue, there have been numbers of studies that hav been conducted by scholars i.e. Husni in his study "The Implementation Of Observe And Remember Game To Improve Students' Vocabulary Mastery At Seventh Grade Of MTs S. Al-Washliyah Tembung" The researcher uses Classroom Action Research. The instrument of collecting data were from interview, observation sheets, diaries, and photographic evidence. Then, qualitative data is analyze of the student scores in the pre-test and post-tests. Research shows that there has been an increase in students' scores in vocabulary mastery by using a game of observation and remembering. (Husni, 2017)

Further more Ruwaida Nusa Putri in her study "The Application of Observe and remember Games in Improving Students' Achievement in Vocabulary at The Seventh Grade of MTs Islamiyah Medan " This study used classroom action research. This study used were taken from interview and observation sheet as the instrument. Tests are gave for learners in form of a initial test, and two final test. The subject of the study consists of 22 students. The study suggests that has been a significant improvement in learner vocabulary mastery. this commit be seen from the average score of initial test and final test, there is significant increase. And the results of observations and interviews indicate that students are instigation in the teaching-learning process during observation and remembering meetings. So this game is succed for use in teaching and in learning processes.(Putri, Nusa, 2017) Besse Kartika (2014) in her study investigating the use of vocabulary through snakes and ladders board game at the seventh year of SMPN Bajo. She found that there was a significant balance between the result of the pre-test and post test. She concluded that teaching vocabulary through snake and ladders board game is effective in the seventh year of SMPN 2 Bajo.

\section{METHODS}

\section{Research Design}

This researcher the write be useful pre-experimental method. The method was be useful to know the effectiveness from Remember and Observe Game in teaching vocabulary at the seventh grade of SMPN 2 Palopo. The formula of researcher design was illustrated below: 
$01=$ Initial Test

$\mathrm{X}=$ Treatment

02= Final Test

\section{Variable}

The were two variable the researcher, namely:

1. Observe and remember as independent variable. Game is good way for test abilities for the learners at observing and recall their moment study especial regard English vocabulary.

2. learners vocabulary as dependent variable. The ability of students in English is different, especially, in speaking and writing. If the students have not vocabulary, the students will be difficult to understand to learner about English. To improve students vocabulary can used the Observe and Remember game to teach students and to improve their vocabulary.

\section{Population and Sample}

This population on the researched is seventh grade learners from SMPN 2 Palopo an 2019/2020 academic year. total population 248 learners from eight class. Because the population was only one class so that the taking sample technique is total sampling. The researcher chose the seventh grade to be respondent in this research. There were 31(17 female and 14 male) sample in SMPN 2 Palopo.

\section{Instrument of the Research}

At this study, researchers be useful a vocabulary tests. This initial test and final test. This purpose of the vocabulary tests is to find out this level of student vocabulary. This number of tests is 20 items. The forms of the test match picture with words.

\section{Procedure of Collecting Data}

The data will collect through the following procedures:

Pre-test

The author gave the treatment after the learners was given initial test. In The element the author was going for gave the test that was consist of speaking assessment. The test was for measure learners vocabulary before apply Remember and Observe.

\section{Treatment}

After the initial test, author treats students through the game of observing and remembering. Each meeting has different material. The material is objects and images. There are four meetings in this treatment. The steps of the game are as follow:

1. The first meeting on $05^{\text {th }}$ February 2020:

a. The researcher introduced vocabulary particularly part of speech.

b. The author introduced this game.

c. The author explain this rules of playing this game. 
d. Students sat according to the group, then, the students were welcomed to observe one by one the objects provided by researcher into 2 minutes. (Noun thing: in the classroom)

e. After that the players were invited to set for a moment so they can discuss with their group member with the time provided by researchers for 5 minutes.

f. A few moments later the thinking time is up, participants were asked to write down whatever objects they have seen on the paper. Then collected on the table or in researcher.

g. The game ends when there are students left as winners.

h. The researcher wrote vocabulary in the whiteboard that they did not write.

i. Each student in one group was asked to mention the vocabulary on the objects indicated. For example, the researcher showed an eraser, and says "What is this?" And every student in the group was asked to name the item.

j. And the winner of this game is the one who writes the most objects provided by the researcher correctly.

$\mathrm{k}$. The match ends when there is a winner.

l. The winner got a prize.

2. The second meeting 07th February 2020:

a. The researcher introduced particularly part of speech.

b. The author introduced this game.

c. The author explained again this rules of playing game.

d. Students sat according to the group, then, the students were welcomed to observe one by one the objects provided by researchers with the time given by researchers for 2 minutes. (Noun animals)

e. After that the players were invited to set for a moment so they can discuss with their group member with the time provided by researchers for 5 minutes.

f. A few moments later the thinking time is up, participants were asked to write down whatever objects they have seen on the paper. Then collected on the table or in researchers.

g. The game ends when there were students left as winners.

h. The researcher wrote vocabulary in the whiteboard that they did not write.

i. Each student in one group was asked to mention the vocabulary on the objects indicated. For example, the researcher showed an eraser, and says "What is this?" And every student in the group was asked to name the item.

j. And the winner of this game is the one who wrote the most objects provided by the researcher correctly.

$\mathrm{k}$. The match ends when there was a winner.

l. The winner got a prize.

m.

3. The third meeting $12^{\text {th }}$ February 2020:

a. Students sat according to the group. Then, the students were welcomed to observe one by one the objects provided by researcher with the time given by researcher for 2 minutes. (Noun thing, in the kitchen).

b. After that the players were invited to set for a moment so they can discuss with their group member with the time provided by researcher for 5 minutes. 
c. A few moments later the thinking time is up, participants were asked to write down whatever objects they have seen on the paper. Then collected on the table or in researcher.

d. The game ends when there were students left as winners.

e. The author wrote vocabulary in this white board that they did not write.

f. Each student in one group was asked to mention the vocabulary on the objects indicated. For example, the researcher showed an eraser, and says "What is this?" And every student in the group was asked to name the item.

g. And the winner of this game is the one who wrote the most objects provided by the researcher correctly.

h. The match ends when there was a winner.

i. The winner got a prize.

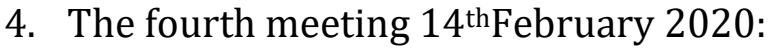

a. Students sat according to the group. Then, the students were welcomed to observe one by one the objects provided by researcher with the time given by researcher for 2 minutes. (Noun thing, in the bathroom).

b. After that the players were invited to set for a moment so they can discuss with their group member with the time provided by researcher for 5 minutes.

c. A few moments later the thinking time is up, participants were asked to write down whatever objects they have seen on the paper. Then collected on the table or in researcher.

d. The game ends when there were students left as winners.

e. The author wrote vocabulary in this white board that they did not write.

f. Each student in one group was asked to mention the vocabulary on the objects indicated. For example, the researcher showed an eraser, and says "What is this?" And every student in the group was asked to name the item.

g. And the winner of this game is the one who wrote the most objects provided by the researcher correctly.

h. The match ends when there was a winner.

i. The winner got a prize.

5. The fifth meeting $19^{\text {th }}$ February 2020:

a. Students sat according to the group. Then, students were welcomed to observe one by one the objects provided by researcher with the time given by researcher for 2 minutes. (Noun animals)

b. After that the players were invited to set for a moment so they can discuss with their group member with the time provided by researchers for 5 minutes.

c. A few moments later the thinking time is up, participants were asked to write down whatever objects they have seen on the paper. Then collected on the table or in researcher.

d. The game ends when there were students left as winners.

e. The author wrote vocabulary in the white board that they did not write.

f. Each student in one group was asked to mention the vocabulary on the objects indicated. For example, the researcher showed an eraser, and says "What is this?" And every student in the group was asked to name the item.

g. And the winner of this game is the one who wrote the most objects provided by the researcher correctly.

$h$. The match ends when there was a winner. 
i. The winner got a prize.

6. The six meeting $21^{\text {th }}$ February 2020:

a. Students sat according to the group. Then students were welcomed to observe one by one the objects provided by researcher with the time given by researcher for 2 minutes. (Noun thing, in the bedroom)

b. After that the players were invited to set for a moment so they can discuss with their group member with the time provided by researcher for 5 minutes.

c. A few moments later the thinking time is up, participants were asked to write down whatever objects they have seen on the paper. Then collected on the table or in researcher.

d. The game ends when there were students left as winners.

e. The author wrote vocabulary in this white board that they did not write.

f. Each student in one group was asked to mention the vocabulary on the objects indicated. For example, the researcher showed an eraser, and says "What is this?" And every student in the group was asked to name the item.

g. And the winner of this game is the one who wrote the most objects provided by the researcher correctly.

h. The match ends when there was a winner.

i. The winner got a prize.

Post-test

After give this treatment, author will gave final test for know this result from learners vocabulary after teaching by through observe and remember.

\section{Technique of Analysis Data}

After analyzing this data, the author will collect this data and analyze them by through procedures as follow:

a. Analyze this raw data from test. Each from the learners correct answers got 1 and this wrong answers got 0 .

b. Score this learners corrected answer of initial test and final test.

$$
\text { Score }=\frac{\text { student }^{\prime} \text { s correct answer total number }}{\text { total number }} \times 100
$$

c. Classifying learners scores based on this follow classification:

1) 81 to 100 are classified as very good

2) 61 to 80 is classified as good

3) 41 to 60 are classified as fair

4) 21 to 40 are classified as poor

5) 1 to 20 as classify is very poor (Kasiran, 1984)

d. Calculate this rate percentages from learners score by through follow formula:

$\mathbf{P}=\frac{\mathrm{F}}{\mathrm{N}} \times \mathbf{1 0 0}$

Where:

$\mathrm{P}=$ percentage

$\mathrm{F}=$ frequency

$\mathrm{N}=$ total sample 
e. Calculating average score, standard deviation, frequency table and test between vocabulary achievement from the pre experimental by through SPSS 20 window to evaluation.

\section{RESULTS}

\section{Findings}

This findings of this study comprised the learners score pre-test and post-test, classification percentage of the learners score in pre-test and post test, the mean score and standard deviation of students' pre-test and post-test.

\section{The Score of Students' Pre-test and Post-test}

Table 4.1 the score from learners initial test and final test

\begin{tabular}{|c|c|c|}
\hline Respondent & Pre-test & Posttest \\
\hline R1 & 25 & 90 \\
\hline $\mathrm{R} 2$ & 55 & 90 \\
\hline R3 & 35 & 85 \\
\hline $\mathrm{R} 4$ & 30 & 100 \\
\hline $\mathrm{R} 5$ & 45 & 100 \\
\hline R6 & 45 & 100 \\
\hline R7 & 60 & 70 \\
\hline $\mathrm{R} 8$ & 55 & 100 \\
\hline $\mathrm{R} 9$ & 50 & 100 \\
\hline $\mathrm{R} 10$ & 25 & 100 \\
\hline $\mathrm{R} 11$ & 55 & 90 \\
\hline $\mathrm{R} 12$ & 55 & 100 \\
\hline R13 & 75 & 100 \\
\hline $\mathrm{R} 14$ & 55 & 100 \\
\hline R15 & 60 & 90 \\
\hline R16 & 40 & 90 \\
\hline $\mathrm{R} 17$ & 55 & 90 \\
\hline R18 & 55 & 100 \\
\hline R19 & 25 & 55 \\
\hline $\mathrm{R} 20$ & 60 & 65 \\
\hline $\mathrm{R} 21$ & 80 & 100 \\
\hline $\mathrm{R} 22$ & 55 & 80 \\
\hline R23 & 80 & 100 \\
\hline $\mathrm{R} 24$ & 35 & 85 \\
\hline $\mathrm{R} 25$ & 55 & 90 \\
\hline $\mathrm{R} 26$ & 45 & 100 \\
\hline $\mathrm{R} 27$ & 30 & 100 \\
\hline $\mathrm{R} 28$ & 75 & 100 \\
\hline $\mathrm{R} 29$ & 50 & 100 \\
\hline
\end{tabular}


Table 4.1 shows that there is a difference between score of the students 'pre-test and score of the student post-test. Because when the students did the pre-test, the researcher not yet gave the treatment to the students. And, why the score of the students' post-test was higher because the researcher already gave the treatment to the students. And most students answer vocabulary about nouns. That happens because, according to students noun are easier rather than adjective(Altenberg, Evelyn; Vago, M., 1393; Eckersley, 1933) and verb.

The Rate Percentage of the Students' Pre-test

Table 4.2 the Rate Percentage Score from learners initial test

\begin{tabular}{llll}
\hline Classification & Score & Frequency & Percentage \\
\hline Very good & $80-100$ & 0 & $0 \%$ \\
Good & $61-80$ & 5 & $17 \%$ \\
Fair & $41-60$ & 17 & $56 \%$ \\
Poor & $21-40$ & 8 & $27 \%$ \\
Very poor & $1-20$ & 0 & $0 \%$ \\
Total & & 30 & $100 \%$ \\
\hline
\end{tabular}

Table 4.2 shows there were 5 (17\%) learners got a good score, $17(56 \%)$ learners got a fairs core, $8(27 \%)$ students got poor score and there was no student got a very good and a very poor score.

The Mean Score and Standard Deviation of the Students' Pre-test

Table 4.3 the average score from learners correct answer initial test Descriptive Statistics

\begin{tabular}{cccccc}
\hline & $\mathrm{N}$ & Minimum & Maximum & Mean $\begin{array}{c}\text { Std. } \\
\text { Deviation }\end{array}$ \\
\hline $\begin{array}{c}\text { Pretest } \\
\text { Valid N }\end{array}$ & 30 & 25 & 80 & 51.00 & 15.614 \\
(listwise) & 30 & & & & \\
\hline
\end{tabular}

Table 4.3 show which the highest score from the learners was 25 and lowest score was 80. Besides, it also indicates which the mean score from learners initial test was 51.00., mean score of students' and the standard deviation of pre-test was 15.614

The Rate Percentage of the Students' Post-test

Table 4.4 the Rate Percentage Score from the Students' Final test

\begin{tabular}{llll}
\hline Classification & \multicolumn{1}{c}{ Score } & Frequency & \multicolumn{1}{c}{ Percentage } \\
\hline Very good & $80-100$ & 26 & $87 \%$ \\
Good & $61-80$ & 3 & $10 \%$ \\
Fair & $41-60$ & 1 & $3 \%$ \\
Poor & $21-40$ & 0 & 0 \\
\cline { 3 - 4 }
\end{tabular}




$\begin{array}{llll}\text { Very Poor } & 1-20 & 0 & 0 \\ \text { Total } & & 30 & 100 \%\end{array}$

Table 4.4 shows there were 26 (87\%) learners got a very good score, $3(10 \%)$ learners got a good score, $1(3 \%)$ learners got fair score and there was no learners got a poor and a very poor score.

The Mean Score and Standard Deviation of the Students' Post-test

Table 4.5 the average Score and Standard Deviation of Students' Post-Test Descriptive Statistics

\begin{tabular}{lccccc}
\hline & N & Minimum & Maximum & Mean & Std. Deviation \\
\hline Posttest & 30 & 55 & 100 & 92.33 & 11.651 \\
Valid N (listwise) & 30 & & & & \\
\hline
\end{tabular}

Table 4.5 show which the highest score from the learners was 100 and the lowest score was 55. Beside, it also indicates which the average score of students' in post-test was 92.33 and the standard deviation was 11.651.

The Mean Score and Standard Deviation of Pretest and Posttest

Table 4.6 the mean score of the students' post-test

Paire d Samples Statistics

\begin{tabular}{lllll}
\hline & Mean & $\mathrm{N}$ & Std. Deviation & Std. Error Mean \\
\hline Pre-test & 51.00 & 30 & 15.614 & 2.851 \\
Posttest & 92.33 & 30 & 11.651 & 2.127 \\
\hline
\end{tabular}

Table 4.6 shows the average score of the learners pre-test was 51.00 and the learners score from post-test was 92.33. Standard deviation from initial test was 15.614 and the standard deviation from final test was 11.651. It means the use of stand up sequences game improved the student's vocabulary.

The Paired Samples Test of Pretest and Posttest

Table 4.7 the paired sample test of pre-test and post-test

Paired Samples Test

\begin{tabular}{|c|c|c|c|c|c|c|c|c|c|}
\hline & \multicolumn{5}{|c|}{ Paired Differences } & \multirow{3}{*}{$\mathrm{T}$} & \multirow{3}{*}{ Df } & \multirow{3}{*}{$\begin{array}{c}\text { Sig. } \\
(2 \text { tailed })\end{array}$} \\
\hline & & \multirow[t]{2}{*}{ Mean } & \multirow[t]{2}{*}{$\begin{array}{c}\text { Std. } \\
\text { Deviation }\end{array}$} & \multirow[t]{2}{*}{$\begin{array}{l}\text { Std. Error } \\
\text { Mean }\end{array}$} & \multicolumn{2}{|c|}{$\begin{array}{l}\text { 95\% Confidence } \\
\text { Interval of the } \\
\text { Difference }\end{array}$} & & & \\
\hline & & & & & Lower & Upper & & & \\
\hline Pair 1 & $\begin{array}{l}\text { Pretest- } \\
\text { Posttest }\end{array}$ & -41.333 & 17.416 & 3.180 & -47.837 & -34.830 & -12.999 & 29 & .000 \\
\hline
\end{tabular}

The hypothesis was tasted by through SPSS 20. In the case, the writer use test (testing of significance) for pair sample test, which is a test for know the significance difference between the result from learners average score in initial test and final test. 
The Probability Value of test of the Students' Achievement

Table 4.8 the Probability Value from Test from learners Achievement

\begin{tabular}{cll} 
Variable & P-Value & $(\alpha)$ \\
\hline $\mathrm{X} 2-\mathrm{X} 1$ & 0.00 & 0.05 \\
\hline
\end{tabular}

Assuming which the level from significance $(\alpha)=0.05$, the only thing which is need; the degree of freedom ( $\mathrm{df}$ ) $=\mathrm{N}-1$, where $\mathrm{df}=34$, which the test is present in the following table.

\section{B. Discussion}

Observe and Remember games is appropriat strategy appli in the classroom in teaching vocabulary. This strategy is help for increase learners interest and enjoy in learn which make them more involve in their vocabulary mastery. The results of the statistical analysis for the significance level of 0.05 with degrees any reedom $(\mathrm{df})=\mathrm{N}-1$, where $(\mathrm{N})$ $=30, \mathrm{df}=34$. Probabili value were smaller than $\alpha(0.00<0.05)$. The show which the alternative hypothesis (H1) was accept and the null hypothesis (H0) was reject. The mean which the Remember and Observe game is effective for improve learners vocabulary. In the beginning of the author, the author explain that the were several procedure use to find out the vocabulary of students. Several tests were conducted to collect data such as pre-test and post-test. Teaching vocabulary through remember and observe game make the teaching and learning process a more enjoy and productive place for both learners and teacher. Remember and observe game commit be a used game to teaching the noun around us because the teacher commit use the thing in the class, in the garden, in the library and in any places. By through the objects and picture given in the class, the learner will remembering strong the new word which we commit get.

This research line with Ruwaida Nusa carried out a research about "The Application from remember and observe Game in improving learners achievement in vocabulary in the seventh grade of MTS Islamiyah Medan in the academic year 2016/2017". Explained that remember and observe Games can improve the learners vocabulary mastery because remember and observe Games has a significant effect to increase the learners vocabulary. She said that the using of Observe and Remember Games is one of the alternative game to teach vocabulary because it has a positive response from the learners. In this author prove which word building is not only improve the learners vocabulary mastery but also it commit upgrade the learners speaking skill and pronounce. In addition, Husni Baraqih(2016) explain the same of benefit of learning include summed up learning motivation, clarifying teaching material, and increasing learners activity especially for disabilities learners. Moreover, it was perceiv which the learners were more eager and intereste learning English, especial for the implementation of the remember and observe game in the learners classroom, it was proved which this method influenc the learners' motivation to study English comfortab. However, it was not denied which there also some weaknesses which found in implement this method. Therefore, the creative and good preparation of every teacher is very essential during the processof implement this method.

In summary, the author assert which remember and observe game is necessary to be applied in teaching vocabulary especial for those and we want to learn it. Observe and Remember game make people easy to learn about vocabulary in the further discussion. 
From the results of previous studies researchers found which using game commit improve the learners vocabulary.

\section{DISCUSSION}

Observe and Remember games is appropriat strategy appli in the classroom in teaching vocabulary. This strategy is help for increase learners interest and enjoy in learn which make them more involve in their vocabulary mastery. The results of the statistical analysis for the significance level of 0.05 with degrees any reedom $(\mathrm{df})=\mathrm{N}-1$, where $(\mathrm{N})$ $=30, \mathrm{df}=34$. Probability value were smaller than $\alpha(0.00<0.05)$. The show which the alternative hypothesis (H1) was accepted and the null hypothesis (H0) was reject. The mean which the Remember and Observe game is useful for improving learners vocabulary. In the beginning of the author, the author explain that the were several procedure use to find out the vocabulary of students. Several tests were conducted to collect data such as pre-test and post-test. Teaching vocabulary through remember and observe game make the teaching and learning process a more enjoy and productive place for both learners and teacher. Remember and observe game commit be a used game to teaching the noun around us because the teacher commit use the thing in the class, in the garden, in the library and in any places. By through the objects and picture given in the class, the learner will remembering strong the new word which we commit get.

This research line with Ruwaida Nusa carried out a research about "The Application from remember and observe Game in improving learners achievement in vocabulary in the seventh grade of MTS Islamiyah Medan in the academic year 2016/2017". Explained that remember and observe Games can improve the learners vocabulary mastery because remember and observe Games has a significant effect to increase the learners vocabulary. She said that the using of Observe and Remember Games is one of the alternative game to teach vocabulary because it has a positive response from the learners. In this author prove which word building is not only improve the learners vocabulary mastery but also it commit upgrade the learners speaking skill and pronounce. In addition, Husni Baraqih(2016) explain the same of benefit of learning include summed up learning motivation, clarifying teaching material, and increasing learners activity especially for disabilities learners.

Moreover, it was perceiv which the learners were more eager and intereste learning English, especial for the implementation of the remember and observe game in the learners classroom, it was proved which this method influenc the learners' motivation to study English comfortab. However, it was not denied which there also some weaknesses which found in implement this method. Therefore, the creative and good preparation of every teacher is very essential during the processof implement this method. In summary, the author assert which remember and observe game is necessary to be applied in teaching vocabulary especial for those and we want to learn it. Observe and Remember game make people easy to learn about vocabulary in the further discussion. From the results of previous studies researchers found which using game commit improve the learners vocabulary.

\section{CONCLUSION}

The author concluded the Remember and Observe game improve learning vocabulary at the seventh grade SMPN 2 Palopo. It could be proven by the learning result of the mean score in the pre-test of initial test was 51.00 and the mean score of the 
learning in the final test was 92.33. After giving treatment to the learning and based on the result of data analysis or the finding, the author found which the $p$ Value was 0.00 and the alpha was 0.05 , therefore $p<\alpha(0.00<0.05)$. It evidence which the null hypothesis $\left(\mathrm{H}_{0}\right)$ was alternative hypothesis $\left(\mathrm{H}_{\mathrm{a}}\right)$ was accept.

\section{REFERENCES}

Altenberg, Evelyn; Vago, M., R. (1393). English Grammar: Understanding the basics. Cambridge University Press.

Eckersley, C. (1933). A Concise English Grammar for Foreign Students.

Ersöz, A. (2000). Six Games for the EFL / ESL Classroom. VI(6).

Husni, B. (2017). The Implementation of Ebserve and Remember Game to Improve Students' Vocabulary Mastery at Seventh Grade of MTs S. Al-Washliyah Tembung. Repository UIN S.UUmatera Utara Medan. https://doi.org/10.1017/CB09781107415324.004

Iksan, M. (n.d.). A SURVEY OF STUDENTS'LANGUAGE LEARNING STRATEGIES AND THEIR ENGLISH LEARNING ACHIEVEMENT IN SMA NEGERI 1 PALOPO.

Putri, Nusa, R. (2017). The Application of Observe and Remember Games in Improving Students' Achievement in Vocabulary at the Seventh Grade of MTs Islamiyah Medan in the Academic Year 2016/2017.

Wright Andrew, Betteridge David, B. M. (2006). Games for Language Learning (Issue 1). Cambridge University Press. https://doi.org/10.16309/j.cnki.issn.10071776.2003.03.004 